\title{
THE EFFECT OF COSTLY-TO-IMITATE CAPABILITIES ON SUSTAINED COMPETITIVE ADVANTAGE IN MANUFACTURING FIRMS IN NIGERIA
}

\author{
Vito Baridula, Ph.D \\ Department of Management, \\ Faculty of Business Studies, \\ Ignatus Ajuru University of Education, Port Harcourt. \\ Mekuri-Ndimele, Joy Adanma, Ph.D \\ Department of Office and Information Management, \\ Faculty of Business Studies, \\ Ignatus Ajuru University of Education, Port Harcourt.
}

\begin{abstract}
The study examined the effect of costly-to-imitate capabilities on sustained competitive advantage in manufacturing firms in Nigeria. A sample size of 248 was determined from a population of 700 respondents using Taro Yamene's sampling technique. Data were collected through structured questionnaire and 248 copies of questionnaire were distributed out of which 232 copies were found useful for data analysis. The data were analyzed using Regression Analysis which was facilitated through Statistical Package for Social Science (SPSS Version 23.0). The findings showed a significant effect of costly-to-imitate capabilities on sustained competitive advantage in manufacturing firms in Nigeria. Based on the findings, the study concludes that costly-to-imitate capabilities significantly affect sustained competitive advantage in manufacturing firms in Nigeria. Hence, the study recommended that management should cultivate a distinctive unique organizational culture that other businesses will find it challenging to emulate. They should establish and pursue ambiguous cause that other firms find it hard to embark on and social complexity that focus on the relationship between managers and employees; managers and directors; the firm and the society (supplier, customers, government and union and associations) in order to gain sustained competitive advantage.
\end{abstract}

Keywords: Costly-to-Imitate Capabilities, Unique organizational culture, Ambiguous cause, Social complexity, Sustained Competitive Advantage 


\section{Introduction}

Manufacturing industry is one of the sectors that contribute immensely to the economic growth of Nigeria. This sector creates employments and helps in building skills in the labour markets. The goods and services provided by this sector have increased the domestic products of the nation (Nigeria) thereby becomes an important factor in the economic development of Nigeria. The fact is that the industry is able to generate personal income as well as providing the industry's income including income tax revenue to the nation. However, the manufacturing industry will become effective if they gained competitive advantage and remain active in the rival business operations.

To achieve competitive advantage, firms need to constantly focus on the identification of differential product strategies, building or reshaping core competencies, acquiring unique technologies, and accumulation of intellectual property, all of which can all be harnessed to make the company successful in a highly competitive marketplace. Identifying what constitutes a core competence has been a subject of debate in the literature for over 20 years (Prahalad \& Hamel, 1990; Aaker, 1989). This problem has become even more complex with globalization and the growth of the internet, which has given open access to more competitive, environmental, and technological information. One key model that was developed in the 1980's modeled core competencies as unique "resources and capabilities". This was known as the resource based view of the firm (Grant, 1991).

Thus, the issue of sustained competitive advantage becomes crucial to the manufacturing industry in Nigeria because research about competitive advantage stretched that the resources are the foundation for strategy, and bundles of resources generate competitive advantage leading to wealth creation. Therefore, in order to be successful in competitive advantage over time, manufacturing firms must think frequently in line with their strategic management process on how to increase value created.

\section{Statement of the Problem}

According to Blyler and Coff (2003), costly-to-imitate capabilities are the firms' capacity to deploy resources that have been properly integrated to achieve the set target such as competitive advantage. Meanwhile, Hitt et al. (2005) assert that the final criterion for a capability to be a source of sustained competitive advantage is that there must be no strategically equivalent valuable resources that are themselves either not rare imitable. In recent times, manufacturing companies in Nigeria have experienced low growth; low sales and undergoing entropy which indicates that many expectations from the sector has not been met in terms of achieving sustained competitive advantage and other benefits.

The challenges have been noticed in the foreign environment in which firms fade out of business operations as a result of intense rival in the sector. Similar situation has also been occurred in manufacturing firms in Nigeria. Although in Nigeria, much attentions have not been given to the causes of business failure thereby led many manufacturing firms in Nigeria to realize minimal chance for survival. It was discovered that these problems emanated from lack of manufacturing firms in Nigeria to develop costly-to-imitate capabilities which other firms will find it difficult to imitate to achieve competitive advantage. The consequences have been disastrous as many firms find it difficult to cope in achieving their set goals. Therefore, it becomes the thrust of this study to investigate the effect of costly-to-imitate capabilities on sustained competitive advantage in manufacturing firms in Nigeria with the 
aim to provide suggestions that will enhance the achievement of sustained competitive advantage in manufacturing firms in Nigeria.

\section{Aim and Objectives of the Study}

The aim of the study was to examine the effect of costly-to-imitate capabilities on sustained competitive advantage in manufacturing firms in Nigeria. However, the specific objectives of the study were to:

1. Examine the effect of unique organizational culture on sustained competitive advantage in manufacturing firms in Nigeria.

2. Determine the association between ambiguous cause and sustained competitive advantage in manufacturing firms in Nigeria.

3. Ascertain the extent to which social complexity affects sustained competitive advantage in manufacturing firms in Nigeria.

\section{Research Questions}

The following research questions were developed to guide the study;

1. What is the effect of unique organizational culture on sustained competitive advantage in manufacturing firms in Nigeria?

2. How does ambiguous cause affect sustained competitive advantage in manufacturing firms in Nigeria?

3. In what ways does social complexity affects sustained competitive advantage in manufacturing firms in Nigeria?

\section{Hypotheses}

The following hypotheses were developed in their null form to guide this study:

Ho$_{1}$ : There is no significant association between unique organizational culture and sustained competitive advantage in manufacturing firms in Nigeria.

Ho2: Ambiguous cause does not significantly affect to sustained competitive advantage in manufacturing firms in Nigeria?

Ho3: Social complexity does not significantly affect sustained competitive advantage in manufacturing firms in Nigeria.

\section{Significance of the Study}

The findings from the study will enhance the performance of managers and non-managerial personnel in decisions making, policy setting and implementation with respect to achieving sustained competitive advantage in manufacturing companies in Nigeria. The study also provided practical situations needing costly-to-imitate capabilities to achieve sustained competitive advantage in manufacturing companies in Nigeria. While managers and nonmanagerial personnel may not be the only category of beneficiaries, scholars will make use of this study as a foundation for future studies where the gap found in the study would be a stepping stone for better understanding of the concept of costly-to-imitate capabilities in the pursuit of sustained competitive advantage. 


\section{LITERATURE REVIEW}

\section{Theoretical Framework}

The resource-based view (RBV), as one of the most widely accepted theories of competitive advantage, focuses on relationships between company's internal resource characteristics and competitive advantage (Spanos \& Lioukas, 2001). It is based on the assumption that companies within an industry are heterogeneous in terms of resources they control. Since resources may not be perfectly mobile, heterogeneity can be long lasting (Barney, 1991). The Resource based view explains that a firm's sustainable competitive advantage is reached by virtue of unique resources being rare, valuable, inimitable, non-tradable, and nonsubstitutable, as well as firm-specific (Makadok 2001; Finney et al, 2004). These authors write about the fact that a firm may reach a sustainable competitive advantage through unique resources which it holds, and these resources cannot be easily bought, transferred, or copied, and simultaneously, they add value to a firm while being rare. It also highlights the fact that not all resources of a firm may contribute to a firm's sustainable competitive advantage. Varying performance between firms is a result of heterogeneity of assets (Helfat \& Peteraf, 2003) and RBV focused on the factors that cause these differences to prevail.

Makadok (2001) emphasizes the distinction between capabilities and resources by defining capabilities as a special type of resource, specifically an organizationally embedded nontransferable firm-specific resource whose purpose is to improve the productivity of the other resources possessed by the firm. Resources are stocks of available factors that are owned or controlled by the organization, and capabilities are an organization's capacity to deploy resources (Amit \& Schoemaker, 1993). Essentially, it is the bundling of the resources that builds capabilities (Sirmon et al., 2007). Therefore, applying Resource Base View Theory in strategic management of resources will enhance the concept of costly-to-imitate capabilities to achieve sustained competitive advantage in manufacturing firms in Nigeria. 


\section{Conceptual Framework}

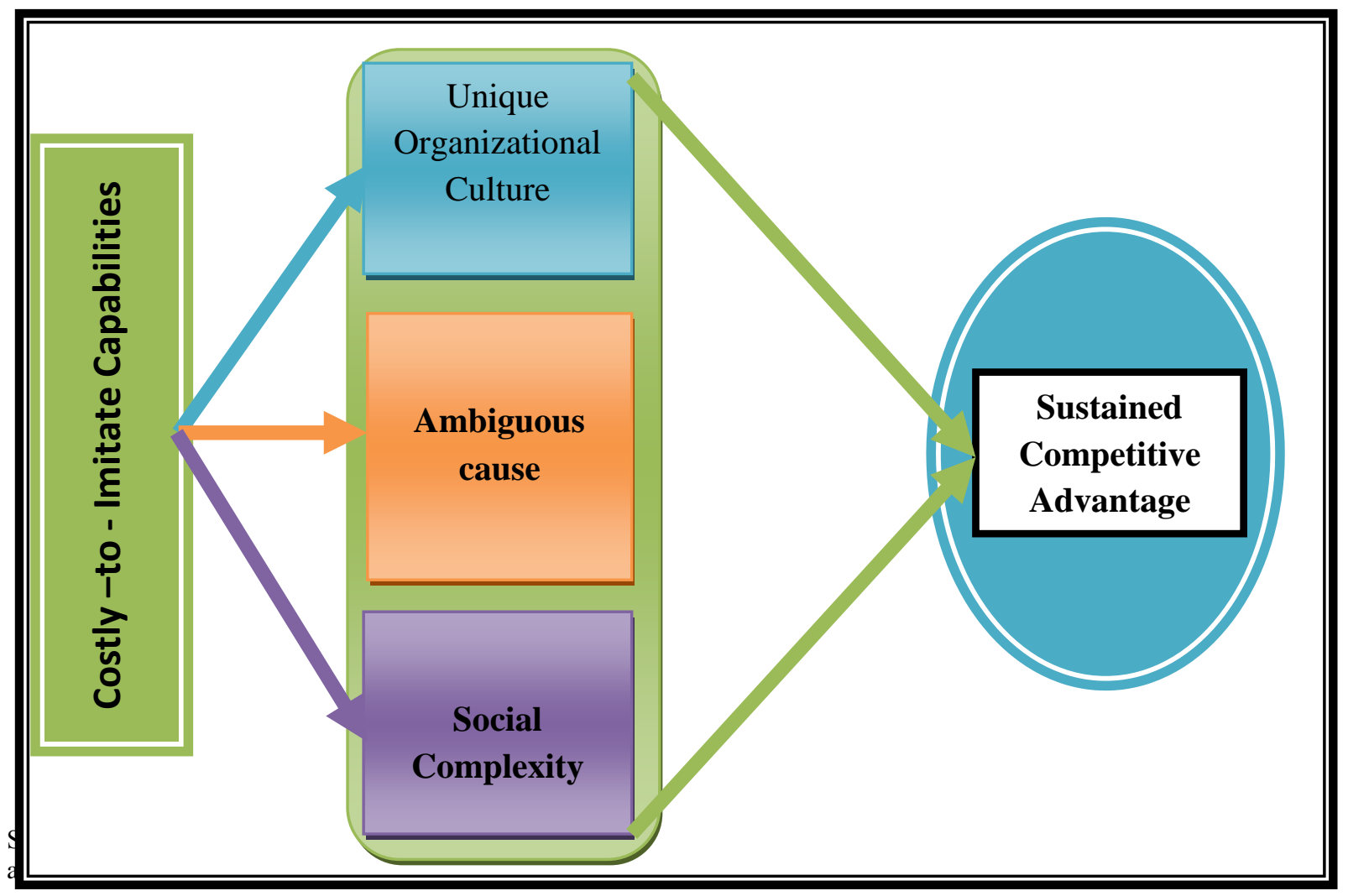

\section{Costly-to-Imitate Capabilities}

A company's capabilities are the activities and functions it performs to utilize its resources in an integrative fashion (Harrison, Hitt, Hoskisson \& Ireland, 2008). Capabilities help the firm to enhance its expertise in a particular functional or operational area. This expertise allows the firm to differentiate itself from competitors. Furthermore, capabilities are operational activities that the firm has mastered. They are incomparable or difficult for competitors to figure out and replicate. When capabilities meet the criteria outlined below, they contribute to the company's competitive advantage and profit potential, and are considered core competencies (Harrison et al., 2008).

When a firm determines its core competencies, it may decide to focus on these activities only, and to outsource other peripheral or non-core activities. Provided that non-core activities can be performed more efficiently and economically by an outside organization that has expertise in that activity, it may benefit the firm to outsource all possible peripheral business activities in order to devote itself to core business activities and competencies (Harrison et al., 2008). Capabilities are costly to imitate when other firms are unable to develop them except at a cost disadvantage relative to firms that already have them. This usually is a result of one or a combination of three conditions: Historical: A unique and a valuable organizational culture.

\section{Unique Organizational Culture}

Clearly identify the corporate culture, values, strategy and a view of the future for employees, suppliers and customers Unique historical conditions can make duplication of capabilities costly. For example, establishing facilities in a key location that can preempt competition when no other locations have similar value-related characteristics or developing a unique 
organizational culture in the early stages of the organization's life may not be cheap to duplicate by firms that are developing theirs at a different time. A unique culture may not only serve as a source of competitive advantage, but also can be a source of competitive disadvantage. The latter may be the case when a firm's culture prevents it from recognizing or successfully adapting to changes in a turbulent environment (Hitt et al., 2005).

\section{Causal Ambiguity}

Causal ambiguity also may prevent competitors from perfectly imitating a competency if the link between a firm's capabilities and core competencies is not identified or understood. Competitors may not be able to identify or determine how a firm uses its competencies to achieve a sustainable competitive advantage (Hitt et al., 2005). The term "causal ambiguity" in its traditional usage refers to any knowledge-based impediment to imitation (Saloner et al., 2001). The first strategy paper using this term appears to be Lippman and Rumelt (1982), who assert, "basic ambiguity concerning the nature of the causal connections between actions and results" can result in persistent performance heterogeneity because "the factors responsible for performance differentials resist precise identification." "Causal ambiguity" is as broadly defined as "the state in which managers do not know how their actions map to consequences," the statement "managers experience causal ambiguity" is indistinguishable from "managers don't know what they're doing," in which case a bias toward plain language should favor the latter. Lippman and Rumelt (1982), state that a particular type of confusion can arise in the context of competitive imitation that is both "causal" and "ambiguous" in a precise sense of both words.

Causal ambiguity is the continuum that describes the degree to which decision makers understand the relationship between organizational inputs and outputs (King 2007). Their argument is that inability of competitors to understand what causes the superior performance of another (inter-firm causal ambiguity), helps to reach a sustainable competitive advantage for the one who is presently performing at a superior level. Holley and Greenley (2005) state that social context of certain resource conditions act as an element to create isolating mechanisms and they quote Wernerfelt (1986) that accumulated skill-based resources acquired through learning, complexity (large number of inter-related resources being used) and specificity (dedication of certain resources to specific activities) will result in a competitive barrier.

\section{Social Complexity}

There must be interpersonal relationships, trust, and friendship among managers, suppliers and customers. Another reason that a firm's resources may be imperfectly imitable is the existence of very complex social phenomena, beyond the ability of firms to systematically manage and influence. When competitive advantages are based on such a phenomena, the ability of other firms to imitate these resources is significantly constrained (Barney, 1991). A wide variety of firm resources may be socially complex for example interpersonal relations among managers in a firm, and a firm's culture (Barney, 1986); a firm reputation among suppliers (Porter, 1980) and customers. It is also to specify how these socially complex resources add value to a firm. Therefore, there is little or no casual ambiguity surrounding the link between these firm resources and competitive advantage. However, organizational culture for example those with certain attributes or quality relations among managers can improve a firm's efficiency and effectiveness which does not necessarily imply that firms without these attributes can engage in systematic effort to create them (Dierickx \& Cool, 1989). 
Physical technology is though not included in this category of sources of imperfect inimitability. Physical technology for example machine tools or robots in factories (Hayes and Wheelwright, 1984) or complex information management systems (Howell and Fleishman, 1982), is by itself typically imitable. If one firm can purchase these physical tools of production and thereby implement some strategies, then other firms should not be a source of sustained competitive advantage. It is only the exploitation of the physical technology in a firm with the use of socially complex firm that can make the resource imperfectly imitable. Several firms may all possess that same physical technology, but only one of these firms may possess the social relations, culture, traditions to fully exploit this technology in implementing strategies (Wilkins, 1989). If these complex social resources are not subject to imitation (and assuming they are valuable and rare and no substitute exists), these firms may obtain a sustained competitive advantage from exploring the physical technology more completely that other firms, even though competing firms do not vary in terms of the physical technology they possess.

\section{Sustainable Competitive Advantage}

One of the key objectives of any business strategy is to achieve competitive advantage that is sustainable (Stonehouse et al., 2004). Competitive advantage thus refers to the condition where the product or service of a firm is perceived to be better than that of its competitors. The most common types of competitive advantage are due to low-price or differentiated products/services. The old school of thought believes that a strategy based on a combination of both low-price and product differentiation will lead to failure. Economies of scale and scope contribute in a major way in retaining a low-price structure. This implies that a strategy will result in better performance in the industry that is sustainable over a period of time. Competitive advantage will lead to superior performance (often assessed in terms of increased profit returns against sales or investment, higher unit revenue, lower unit costs, higher market share (Dirisu, Iyiola \& Ibidunni, 2013).

\section{Method}

The study adopted cross sectional research design. The population of the study was seven hundred (700) respondents comprising of managers and non-managerial personnel from seven (7) manufacturing companies in Nigeria. These firms were; Dangote group of companies, Nigeria Bottling Co. Plc, Pabod Breweries, Madonna Paints, Eastern Bulkcem Co. Ltd, First Aluminum Co. and Triumph Drinks Ltd. A sample size of 248 was determined from this population through Krejcie and Morgan sample table. The data were collected through questionnaire. The variables were measured using four item statements each on Likert 4-point scale. The study adopted face and content validity and the reliability of the instrument was ascertained using Cronbach Alpha test. The following results were achieved from the test;

Unique organizational culture scored 0.84 , no. of items $=4$. Causal ambiguity scored 0.86 , no. of items $=4$. Social complexity scored 0.89 , no. of items $=4$ and sustainable competitive advantage scored 0.93 , no. of items $=4$. The above results indicate that the instrument for the study met the standard for measuring the variables. The data collected were analyzed using Linear Regression Analysis to ascertain the effect of the predictor variables on the criterion variable.

\section{Results and Discussion}

Two hundred and forty eight (248) managers and non-managerial personnel were reached with the questionnaire and two hundred and thirty two (232) copies were filled and retrieved 
successfully. This shows that the participants responded favourably to the items on the questionnaire. Table 1 below shows the results from demographic analysis.

Table 1: Demographic data analysis

\begin{tabular}{|l|l|l|}
\hline Response Variables & No of Respondents & Respondents' (\%) \\
\hline Gender: & & \\
\hline Male & 129 & 55.6 \\
\hline Female & 103 & 44.4 \\
\hline Total & 232 & $\mathbf{1 0 0 \%}$ \\
\hline Age: & Frequency & Percentage \\
\hline $25-35$ years & 64 & 27.6 \\
\hline $35-45$ years & 70 & 30.2 \\
\hline $45-55$ years & 55 & 23.7 \\
\hline Above 55 years & 43 & 18.5 \\
\hline Total & 232 & $\mathbf{1 0 0 \%}$ \\
\hline Levels of Qualifications & Frequency & Percentage \\
\hline Diploma & 104 & 44.8 \\
\hline First Degree & 68 & 29.3 \\
\hline Master's Degree & 48 & 20.7 \\
\hline Ph.D. Degree & 12 & 5.2 \\
\hline Total & 232 & $\mathbf{1 0 0 \%}$ \\
\hline Positions & Frequency & Percentage \\
\hline Management & 98 & 42.2 \\
\hline Supervisor & 113 & 48.7 \\
\hline Non-managerial personnel & 21 & 9.1 \\
\hline Total & 232 & $\mathbf{1 0 0}$ \\
\hline Years of experience with the Firm & Frequency & Percentage \\
\hline 1-5 year & 70 & 30.2 \\
\hline 6-10 years & 58 & 25.0 \\
\hline 11-15 years & 45 & 19.4 \\
\hline 16-20 years & 35 & 15.1 \\
\hline Above 20 years & 24 & 10.3 \\
\hline Total & 232 & $\mathbf{1 0 0}$ \\
\hline Source: Fien ren & \\
\hline & & \\
\hline
\end{tabular}

Source: Field research data (2020)

The table above shows that $129(55.6 \%)$ of the respondents were male while the female were $44.4 \%$ of the total respondents. It shows that the majority of respondents were male since they had higher respondents' distribution than the female.

For age of respondents, the result indicates that majority of the respondents were between $35-45$ years which represents $30.2 \%$ of the total respondents, followed by 64 between $25-$ 35 years represented by $27.6 \%$. Furthermore, 55 respondents between $45-55$ years representing $23.7 \%$ and only 43 were above 5 years represented by $18.5 \%$.

With respect to Levels of educational qualifications the result indicates that majority of the respondents are holders of Diploma which represents $44.8 \%$ of the total respondents, followed by $68(29.3 \%)$ respondents with first degree, while 48 respondents representing $20.7 \%$ are master's degree holders and only 12(5.2\%) were Ph.D degree holders. 
From the point of position in the organization, top management were 98 representing $42.2 \%$ while 113 respondents were supervisors representing 48.7\%, and the Non-managerial personnel were 21 representing $9.1 \%$. The analysis shows that majority of the respondents were supervisors.

\section{Univariate Analysis of the items on the Questionnaire}

Likert's four point scale was adopted. The criterion mean as benchmark was computed as followed: Acceptable Mean $=\frac{1+2+3+4}{4}=2.5$. This shows that only responses to items that meet the criterion mean benchmark were accepted for the study.

Table 2. Descriptive Statistics

\begin{tabular}{|l|r|r|r|}
\hline & Mean & Std. Deviation & $\mathrm{N}$ \\
\hline Sustained Competitive Advantage & 3.0690 & 1.57482 & 232 \\
Unique Organizational Culture & 3.3405 & 1.52908 & 232 \\
Ambiguous cause & 3.2716 & 1.41405 & 232 \\
Social Complexity & 3.0043 & 1.35000 & 232 \\
\hline
\end{tabular}

Source: SPSS Output (2021)

From table 2 above, it is clear that the means core of all items for the variables were above 2.5 criterion mean. This implies that the data for the study were in good fit and the respondents actually provided responses required for the study.

\section{Test of Hypotheses}

The null hypotheses formulated were tested to ascertain the influence of the predictor variables (Social Complexity, Ambiguous cause, Unique Organizational Culture) on the criterion variables (Sustained Competitive Advantage) as shown on table 3

Table 3

Model Summary

\begin{tabular}{|c|c|c|c|c|c|c|c|c|c|}
\hline \multirow[b]{2}{*}{ Mode } & \multirow[b]{2}{*}{$\mathrm{R}$} & \multirow[b]{2}{*}{$\begin{array}{c}R \\
\text { Square }\end{array}$} & \multirow[b]{2}{*}{$\begin{array}{l}\text { Adjusted R } \\
\text { Square }\end{array}$} & \multirow{2}{*}{$\begin{array}{c}\text { Std. Error of } \\
\text { the } \\
\text { Estimate }\end{array}$} & \multicolumn{5}{|c|}{ Change Statistics } \\
\hline & & & & & $\begin{array}{c}\text { R Square } \\
\text { Change }\end{array}$ & $\begin{array}{c}\mathrm{F} \\
\text { Change }\end{array}$ & $\mathrm{df1}$ & $\mathrm{df} 2$ & $\begin{array}{c}\text { Sig. F } \\
\text { Change }\end{array}$ \\
\hline 1 & $.972^{\mathrm{a}}$ & .945 & .944 & .37298 & .945 & $\begin{array}{r}1296.74 \\
6\end{array}$ & 3 & 228 & .000 \\
\hline
\end{tabular}

a. Predictors: (Constant), Social Complexity, Unique Organizational Culture, Ambiguous cause

b. Dependent Variable: Sustained Competitive Advantage

From table 3, the value of 0.972 indicates a good level of prediction. The "R Square" of 0.945 is the $\mathrm{R}^{2}$ value the coefficient of determination, which is the proportion of variance in the dependent variable that can be explained by the independent variables. Hence, from table 3, $5.5 \%(100 \%-94.5 \%)$ of the variation is caused by factors other than the predictors included in this model. Thus, $94.5 \%$ proportion of variance in sustained competitive advantage is explained by social complexity, ambiguous cause and unique organizational culture. 


Table 4.
\begin{tabular}{|ll|r|r|r|r|r|}
\hline Model & & ANOVA & \multicolumn{1}{c|}{ Sig. } \\
\hline 1 & Regression & Sum of Squares & \multicolumn{1}{|c|}{ df } & Mean Square & F & Sig \\
& Residual & 541.179 & 3 & 180.393 & 1296.746 & $.000^{\circ}$ \\
& 31.718 & 228 & .139 & & \\
& Total & 572.897 & 231 & & & \\
\hline
\end{tabular}

a. Dependent Variable: Sustained Competitive Advantage

b. Predictors: (Constant), Social Complexity, Unique Organizational Culture, Ambiguous cause

The F-ratio in the ANOVA Table 4 tests whether the overall regression model is a good fit for the data. The result shows that social complexity, ambiguous cause and unique organizational culture statistically and significantly predict Sustained competitive advantage, $\mathrm{F}(3,228)=180.393, \mathrm{p}(.000)<.05$ indicates that the regression model is a good fit of the data.

Statistical Significance of the Independent Variables:

Statistical significance of each of independent variables measures whether the nonstandardized (or standardized) coefficients were equal to 0 (zero) in the population (i.e. for each coefficient, $\mathrm{H} 0: \beta=0$ and $\mathrm{Ha}: \beta \neq 0$ ). If $\mathrm{p}<.05$, the coefficients are statistically significantly different from 0 (zero). The importance of these significant tests is to examine whether each test is valid.

Table 5.

\begin{tabular}{|c|c|c|c|c|c|c|}
\hline \multirow{2}{*}{\multicolumn{2}{|c|}{ Model }} & \multicolumn{2}{|c|}{ Unstandardized Coefficients } & $\begin{array}{l}\text { Standardized } \\
\text { Coefficients }\end{array}$ & \multirow[b]{2}{*}{$\mathrm{t}$} & \multirow[b]{2}{*}{ Sig. } \\
\hline & & $\mathrm{B}$ & Std. Error & Beta & & \\
\hline & (Constant) & -.427 & .062 & & -6.877 & .000 \\
\hline & $\begin{array}{l}\text { Unique Organizational } \\
\text { Culture }\end{array}$ & .335 & .059 & .325 & 5.681 & .000 \\
\hline & Ambiguous cause & .253 & .079 & .227 & 3.213 & .002 \\
\hline & Social Complexity & .516 & .054 & .442 & 9.642 & .000 \\
\hline
\end{tabular}

a. Dependent Variable: Sustained Competitive Advantage

Given that, the t-value and corresponding p-value are in the "t" and "Sig." columns respectively, the tests indicates that the standardized coefficient with beta value for unique organizational culture is 0.325 when $\mathrm{p}(.000)<0.05$ is significant; ambiguous cause when $\mathrm{p}(.000)<0.05$ is significant with moderate effect of 0.227 and social complexity is 0.442 when $\mathrm{p}(.000)<0.05$ is significant. This means that all predictor variables have a significant effect on sustained completive advantage. However, the highest effect occurs at 0.442 representing the effect of social complexity on sustained competitive advantage

\section{Discussion of Findings}

A simple regression was run to analyze the effect of unique organizational culture, ambiguous cause and social complexity on sustained competitive advantage. The model statistically and significantly predicted unique organizational culture, ambiguous cause and social complexity highly on sustained competitive advantage. This proves that costly-toimitate capabilities affect sustained competitive advantage in manufacturing firms in Nigeria.

This finding is supported by the work of Maket (2016). Maket (2016) conducted an observational study on the effect of resource non-substitutability on long-term competitiveness. The study is grounded on the Resource Based View (RBV) model (RBV and the balanced scorecard). Competitive advantage is closely linked to a company's internal 
characteristics, according to RBV of strategic management (value, rarity, inimitability and non-substitutability). A total of 262 people were chosen from two Kenyan universities (one private and one public). The results of the study showed that the public university outperformed the private university in terms of resource non-substitutability. This is possible because the resources were costly to imitate and were difficult to find. Despite the fact that $\mathrm{RBV}$ is one of the most influential theories of strategic planning, the study provides empirical proof of resource non-substitutability's on service sector sustainability.

Srivastava, Franklin and Martinette (2013) also review the concept of resources that are difficult to imitate, like differentiation of products to gain competitive advantage. They followed Barney (1991) in the ideas that in order to create a true cost or differentiation advantage, a firm's resources and capabilities must be: valuable - resources that is unique and will improve the company efficiency or effectiveness in order to outperform its competitors or reduces its competitive weaknesses. Rare - resources that are hard to find, unique and cannot be found by other companies. Imperfectly imitable - resources that are very hard to imitate, allowing sustainably because without huge investment of limited resources, competitors find it difficult to enter the market. Non-Substitutable - resources that have no real equivalence that itself is not rare or imitable (Srivastava et al., 2013).

\section{Conclusion}

The research reveals that in Nigerian manufacturing companies, costly-to-imitate capabilities have a significant effect on sustained competitive advantage. This arose from the fact that Nigerian manufacturing companies failed to consider costly to imitate capabilities as a strategy to outperform their competitors. As a result of the study, unique organizational culture has an effect on sustained competitive advantage. In manufacturing firms in Nigeria, the ambiguous cause also impacted on sustained competitive edge, this was followed by social complexity. As a conclusion, the findings prove that in Nigerian manufacturing companies, costly-to-imitate capacities have an effect on sustainable competitive advantage.

\section{Recommendations}

According to the study's findings and conclusion, management should build companyspecific expertise that will help the company outperform rivals and achieve a sustainable competitive advantage. In order to maintain a sustainable competitive edge in Nigerian manufacturing firms, management should also cultivate a distinctive unique organizational culture that other businesses will find it challenging to emulate. They should establish and pursue ambiguous cause that other firms find it hard to embark on and social complexity that focus on the relationship between managers and employees; managers and directors; the firm and the society (supplier, customers, government and union and associations) in order to gain sustained competitive advantage.

\section{Contributions to Knowledge}

This study actually examines the effect of costly-to-imitate capabilities on sustained competitive advantage in manufacturing firms in Nigeria. As such, it developed a framework that captured the extent to which costly-to-imitate capabilities will enhance sustained competitive advantage in literature. Additionally, this helps in expanding the concept of costly-to-imitate capabilities and sustained competitive advantage which are limited in literature. Hence, scholars can assess the findings and the gap in the present study and use it to improve future research as relates to this area. 


\section{Areas for Future Studies}

The study examines the effect of costly-to-imitate capabilities on sustained competitive advantage in manufacturing firms in Nigeria. The study focused on how costly to imitate capabilities can be more effectively to build, augment or sustain a firm's core competencies. As an area of future research, it is possible to dive further in each area discussed in the study in order to gain a deeper understanding of the relative influence of these factors on a firm's ability to remain competitive in the longer term. However, due to diversity of today's companies, i.e. globalization, multi-cultural companies, pace of technology and new environmental and economic factors, a given industry would be interesting to build on the study by refining the survey to probe deeper in certain areas to give more insight into: highly valued resources and strategies for a successful operation: Company's culture that provide edge competitive advantage: innovation and creativity success factors for higher trust customer relationships that will drive the faster to outperform its rivals. 


\section{References}

Aaker, D. (1989). Building strong brands: Free press.

Amit, R., \& Schoemaker, P. (1993). Strategic assets and organizational rent. Strategic Management Journal. 14, 33-46.

Barney, J. B. (1991). Firm resources and sustained competitive advantage. Journal of Management, 17(1), 99-120.

Blyler, M. \& Russell, C. (2003). Dynamic Capabilities, Social Capital, and Rent Appropriation: Ties That Split Pies. Strategic Management Journal. 24, 677-686.

Finney, S. J., Pieper, S. L., \& Barron, K. E. (2004). Examining the psychometric properties of the Achievement Goal Questionnaire in a general academic context. Educational and Psychological Measurement, 64, 365-382

Grant, R.M. (1991). The resource-based theory of competitive advantages: implications for strategy formulation. California Management Review, 33(3), 114-135.

Grant, R., Butler, B., Orr, S., \& Murray, P. (2014). The VRIO Framework: Evaluating Competitive Resources and capabilities. Contemporary Strategic Management, $.174-177)$.

Harrison, Jeffrey S., Michael A. Hitt, Robert E. Hoskisson, R. Duane Ireland. (2008). Competing for Advantage, Thomson South-Western, United States.

Helfat, C. E. \& Peteraf, M. A. (2003). Managerial cognitive capabilities and the microfoundations of dynamic capabilities. Strategic Management Journal, 36(6),831-850.

Hitt, M.A., Ireland, R. \& Hoskisson, R.E. (2005). Strategic management competitiveness and Globalization concepts $\left(6^{\text {th }}\right.$ ed.) Trompson South-Western U.S.A

Hooley, G. and Greenley, G. (2005) The Resource underpinnings of competitive positions. Journal of Strategic Marketing. 13(2): 93-116.

Howell, W. C. \& Fleishman, E. A. (1982). Human Performance and Productivity. Journal of Organizational Behaviour. 2: 193

Dirisu, J.I. Iyiola, O. \& Ibidunni, O.S. (2013). Product differentiation: a tool of competitive advantage and optimal organizational performance (a study of unilever Nigeria plc). European Scientific Journal 9(3), 4-6.

Lippman, S. \& Rumelt, R. (1982). Uncertain Imitability: An analysis of Inter-firm Differences in Efficiency under Competition', Bell Journal of Economics $\backslash$

Makadok, R. (2001). Toward a synthesis of the resource-based and dynamic-capability views of rent creation. Strategic Management Journal, 22(5), 387-401

Maket, L.J. (2016). Resource Non-Substitutability as a Predictor of Sustainable Competitiveness. International Journal of Management and Commerce Innovations, 4(2), 824-829. 
Prahlad, C. K., \& Hamel, G. (1990). The core competence of the corporation. Harvard Business Review, 68 (3) 79-91.

Saloner, S. \& Podolny (2001). Strategic management. John Wiley \& Sons, 3-6.

Sharkie R. (2003). Knowledge creation and its place in the development of sustainable competitive advantage», Journal of knowledge management, 7(1), 3-5

Sirmon, D. G., Hitt, M. A., \& Ireland, R. D. (2007). Managing firm resources in dynamic environments to create value: Looking inside the black box. Academy of Management Review, 32(1), 273-292

Spanos, Y. E., \& Lioukas, S. (2001). An examination into the causal logic of rent generation: contrasting Porter's competitive strategy framework and the resource based perspective. Strategic Management Journal, 22(10), 907-934.

Stonehouse, G., Campbell, D., Hamill, J., Purdie, T., (2004). Global and Transnational Business: Strategy and Management. John Wiley \& Sons Ltd., 4-7, 158-188

Srivastava, M., Franklin, A. \& Martinette, L. (2013). Building a Sustainable Competitive Advantage. Journal of Technology Management \& Innovation, 8(2), 2-7.

Birger Wernerfelt, B. The relation between market share and profitability. Journal of Business Strategy, 4-6

Wilkins, A. L. (1990). Developing corporate character https://doi.org/10.1177/017084069001100320 